\title{
New French government aims to boost research job pros pects
}

[PARIS] Research and technology are likely to move up the political agenda in France following the victory of the Socialist party and its allies in last weekend's general election. But the government's room for manoeuvre will in practice be sharply curtailed by the overriding need to keep public spending in check in order to meet the Maastricht criteria for entry into European Monetary Union.

The Socialist party has not yet drafted a fully fledged manifesto for science, mainly because its plans to do so were pre-empted by the decision of Jacques Chirac, the French president, to call a snap election. But one likely outcome, according to Claudine Laurent, a member of the Socialist party's committee on science, is the immediate launch of initiatives to boost job opportunities for young researchers.

The government aims to ease the stagnation in recruitment that has occurred in the public research organizations over the past five years, in particular to offset the expected massive wave of retirement over the next decade; more than half the current research workforce is expected to retire by 2005 .

But constrained by the need to limit public spending on the one hand, and keen to increase research in the private sector, the government also intends to encourage the recruitment of scientists by companies, especially the small and medium-sized. One idea is to link recruitment directly to the tax incentives given to companies that carry out research, worth about FFr4 billion (US\$696,000,000) a year.

It is still far from clear how research will be organized at government level. Some French newspapers have predicted the creation of a superministry of industry, higher education and research, headed by Claude Allègre, a researcher at the Institut de Physique du Globe de Paris. But Allègre is being widely tipped as science minister primarily because he is a close friend and principal adviser of Lionel Jospin, the first secretary of the Socialist party and new prime minister (see Nature 374, 666; 1995).

Sources close to the party say Jospin would be unlikely to refuse Allègre a ministerial portfolio should he ask for it. But they point out that while Allègre is widely respected as an intelligent and staunch defender of research and education, his bruising, singled-minded style runs contrary to the consensual government promised by Jospin. Nevertheless, there is general agreement in Paris that Allègre is guaranteed a key post, perhaps as adviser to Jospin or as head of one

NATURE|VOL 387| 5 JUNE 1997 of France's major research agencies.

Nor is the creation of a superministry a foregone conclusion. One option raised frequently at a series of $a d$ hoc meetings held over the past few weeks by the Socialist party and leading scientists and research administrators is the need to separate education from research. They were brought together in one ministry in 1993 by the then prime minister Edouard Balladur. But there is general agreement that the heavy day-to-day demands of the school and higher-education portfolios has led to a neglect of research.

A major challenge facing the new government is widely seen to be the development of a coherent national strategy for research in consultation with the various actors involved, and many scientists remain sceptical about its ability to do this. Another is tackling the long-standing problem of the large proportion, often more than threequarters, of the research agencies' budgets taken up by salaries. This leaves little money for the strategic programmes that many feel are needed to reinvigorate French research.

The coming months are also likely to bring changes in the individuals responsible for running the research agencies. Guy Aubert, director-general of the national research agency CNRS, finishes his current mandate in July, and Claude Griscelli, the directorgeneral of the national biomedical research agency INSERM, is partway through his mandate. Although new governments traditionally allow existing mandates to expire, many observers predict they may make an exception for Griscelli, who is an associate mayor for health in Paris in a town hall racked by financial scandals.

Declan Butler See also: synchrotron siting row, page 539

\section{Russian academy elects younger blood}

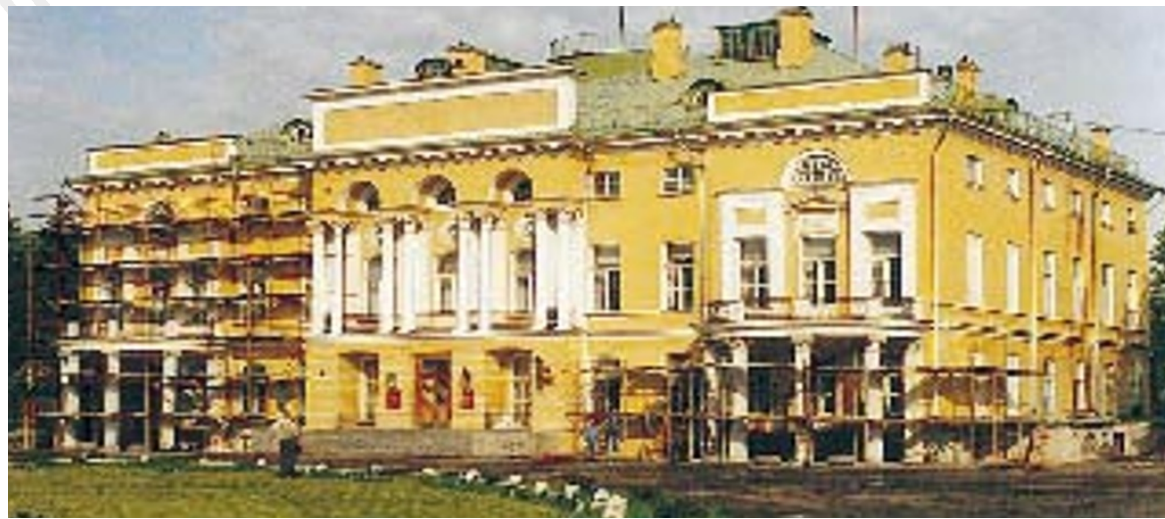

[MOscow] The Russian Academy of Sciences is, like its headquarters building in Moscow (above) being given a facelift. In addition to filling more than 100 'natural' vacancies resulting from the deaths of former members over the past three years in elections last week, the government had provided money for 50 additional full members younger than 55 , and 100 new corresponding members younger than $\mathbf{5 0}$.

But, partly as a result of the controversy created by this move - some members had argued that scientific achievement should be the sole factor - not all the vacancies were filled. Only 61 new full members (including 16 'young') and 189 corresponding members (83 'young') were elected.

Further controversy was created by some political figures seeking election. Those successful included Mikhail Kirpichnikov, who heads the cabinet's department of science and education and who, it is said, was responsible for the government's decision to help 'young' scientists (like himself) to be elected to the academy.

Others appointed to full membership included Viktor Mokhailov, the minister for atomic energy, and Viktor Sadovnichy, the rector of Moscow University. But Andrey Kokoshin, first deputy minister of defence, failed to win sufficient support, even though he was the only candidate for the vacancy.

Other political figures who failed to be elected included Alexander Shokhin, deputy speaker of the State Duma (Russian parliament), Alexey Egorov, deputy minister of science and technology, and three active politicians, Sergey Glaziev, Alexander Arbatov and Viktor Shevelukha.

Among those elected was Alexander Solzhenitsin, the writer and former dissident, who was recognized for his contributions to the enrichment of the Russian language.

Carl Levitin 